\title{
The Effects of Kinesio Taping on Reaction Time, Pain, Hand Grip Strength and Upper Extremity Functional State in Patients with Lateral Epicondylitis
}

\author{
Lateral Epikondilitli Hastalarda Kinezyo Bantlama Uygulamasının Reaksiyon Zamanı, \\ Ağrı, Eı Kavrama Kuvveti ve Üst Ekstremite Fonksiyonuna Etkisi
}

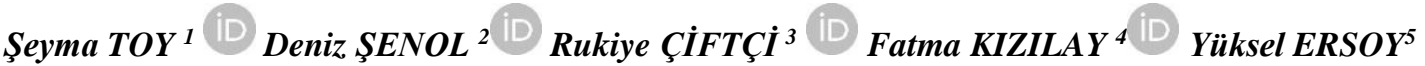

\section{ÖZ:}

Amaç. Bu çalışmanın amacı lateral epikondilitli (LE) hastalarda konvansiyonel fizyoterapi yöntemlerine ek olarak uygulanan kinezyo bantlama uygulamasının (KB) görsel reaksiyon zamanı (GRZ) ve işitsel reaksiyon zamanı (IRT), ağrı, el kavrama kuvveti (EKK) ve üst ekstremite fonksiyonu üzerine olan etkilerini değerlendirmektir.

Araçlar ve Yöntem: Bir üniversite hastanesinde fiziatrist tarafından LE tanısı konulan 70 hasta çalışmaya dahil edildi. LE'li hastalar randomize olarak "inhibisyon KT" (IKB) ve "sahte KT" (SKB) gruplarına ayrıldı. Vizuel Analog Skala'da (VAS) istirahat (VAS-I), hareket (VAS-H) ve gece (VAS-G) değerlendirmeleri ayrı ayrı yapıldı. GRZ-IRZ değerlendirmesi için Hubbard Scientific reaksiyon zamanlayıcı, fonksiyonel durum değerlendirmesi için Hızlı Kol, Omuz, El Sakatlık Ölçeği ve EKK için Jamar el dinamometresi ölçümleri tedavi öncesi ve tedavi sonrası karşılaştırmalar için kaydedildi.

Bulgular: Tedavi öncesi ve sonrası grup içi karşılaștırmada her iki grubun tüm parametrelerde istatistiksel olarak anlamlı iyilessme gösterdiği belirlendi $(\mathrm{p}<0.05)$. Grupların tedavi sonrası verileri karşılaştırıldığında ise VAS-H, VAS-İ, GRZ ve İRZ skorlarının İKB grubunda istatistiksel olarak anlamlı azalma gösterdiği tespit edildi $(\mathrm{p}<0.05)$.

Sonuç: Bu çalışmada, konvansiyonel fizyoterapiye ek olarak uygulanan KT’nin LE'nin konservatif tedavisinde etkili bir yöntem olduğunu gösterildi. Her iki grubun tedavi sonrası sonuçları karşılaştırıldığında ağrı, reaksiyon zamanı (RZ) skorlarında IKT grubu lehine istatistiksel olarak anlamlı fark bulundu.

Anahtar kelimeler: ağr1; el kavrama kuvveti; kinezyo bantlama; lateral epikondilit; reaksiyon zamanı

\section{ABSTRACT:}

Purpose: This study aims to evaluate the effects of kinesio taping (KT) in addition to conventional physiotherapy methods, on visual reaction time (VRT) and auditory reaction time (ART), pain, handgrip strength (HGS), and upper extremity function in patients with lateral epicondylitis (LE).

Materials and Methods: 70 patients diagnosed with LE by a physician in a university hospital were included in the study. Patients with LE were randomly divided into "Inhibitory KT" (IKT) and "Sham KT" (SKT) groups. Visual Analog Scale (VAS) measures were made at rest (VAS-R), with movement (VAS-M), and at night (VAS-N) separately. Hubbard Scientific reaction timer for VRTART assessment, quick disability of the arm, shoulder, and hand questionnaire (Quick DASH) for the functional state, and Jamar hand dynamometer measurements for HGS were recorded for pre-treatment and post-treatment comparisons.

Results: In pre-treatment and post-treatment group comparison, it was found that both groups showed statistically significant recovery in all parameters $(\mathrm{p}<0.05)$. When post-treatment data of the groups were compared, it was found that VAS-M, VAS-R, VRT, and ART scores showed a statistically significant decrease in the IKT group $(\mathrm{p}<0.05)$.

Conclusion: The present study shows that KT application in addition to conventional physiotherapy was an effective method in LE's conservative treatment. Statistically significant differences were found on pain, reaction time (RT) scores in favor of the IKT group when the post-treatment results of both groups were compared.

Keywords: handgrip strength; lateral epicondylitis; kinesio taping; pain; reaction time

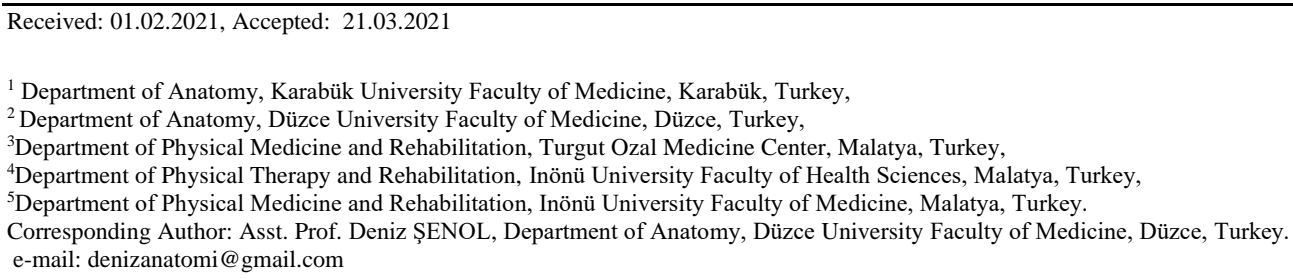




\section{INTRODUCTION}

Lateral epicondylitis (LE) is a common musculoskeletal system disease affecting the wrist extensor tendons that may be associated with professional or psychologi$\mathrm{cal} /$ physiological factors, with a prevalence of $1-3 \%$ in the general population, while its incidence increases up to $19 \%$ between the ages of 30 and $60{ }^{1,2}$ It is noteworthy that it is frequently seen in women and on the dominant side. ${ }^{2}$

Although the pathogenesis of LE is not clear yet, Kraushaar et al. stated that it was caused by injury due to overuse and improper healing in tissue, or they defined it with the definition of "angiofibroblastic tendinosis" which is used to describe recurrent micro-trauma caused by degenerative changes. As recurrent tissue damage continues in patients, progressive degeneration causes pain, losses in strength, and functionality. ${ }^{3}$

It has been reported in the literature that conservative and medical treatment is effective in acute stages, while surgery is effective in advanced calcified states. ${ }^{4}$ The purpose of frequently used conservative treatments is to reduce pain, control tendon-bearing loads, regain flexibility and strength, and thus to inhibit functional regression resulting from pain. Although the rare use of surgical methods in patients with LE increases the significance of conventional treatment, Chard and Hazleman ${ }^{5}$ reported that more than 40 conventional treatment methods were used for LE while there wasn't sufficient evidence for the effectiveness of treatment methods due to methodological differences. ${ }^{6}$

In recent years, one of the conventional treatment options with increasing popularity is kinesio taping (KT). ${ }^{7}$ Physiological effects of KT can be listed as decreasing pain or abnormal sensations, helping the drainage of lymphatic fluid and blood under the skin, and correcting joint arrangement. Because of these effects, it is used in clinics as one of the alternative methods in the treatment of LE, like other musculoskeletal system diseases. However, there are not enough studies in the literature about the use of KT in LE. ${ }^{8}$
Reaction time (RT) is the time that passes between the presentation of a sensory stimulus and reaction. Achieving perfection in RT is possible only if the central nervous system and musculoskeletal systems work in harmony. ${ }^{9}{ }^{10} \mathrm{~A}$ study has been reported that RT, which affects functionality and daily life and neuromuscular performance of the individual, is affected by pain. ${ }^{11}$

There is consensus in the literature on the increasing pain in the elbow area as well as decreased muscle strength in wrist extensors in LE. ${ }^{12,13}$ This may affect the motor component of RT, which is known to be the first response to visual and auditory stimuli for the upper extremity.

In literature, KT use in LE treatment is not a new treatment option. ${ }^{12,14}$ However, in the literature we were able to access, we could not find any studies evaluating the effects of visual reaction time (VRT) and auditory reaction time (ART) in patients with LE. This study aims to evaluate the effects of KT applied in addition to conventional treatment on pain, upper extremity functional state, handgrip strength (HGS), VRT, and ART.

\section{MATERIALS and METHODS}

2019/129 numbered permission of Malatya Clinical Researches Ethical Board was taken to carry out the present study (Date: 03/07/2019). The study was conducted following the principles of the Declaration of Helsinki. The study included 70 patients between the ages of 24 and 67 who were diagnosed with LE by a physician in an outpatient clinic.

Each participant gave their written informed consent. Age, height, weight, body mass index (BMI), and dominant hands of the patients were found. Hand preferences were found with the "Oldfield Handedness Inventory". ${ }^{15}$ Age was calculated in years. Height was measured in $\mathrm{cm}$ with the patients standing with bare feet on a steel stadiometer with a precision of $0.1 \mathrm{~cm}$ while weight was measured in $\mathrm{kg}$ with the patients standing with bare feet without metal by using Tanita BC Segmental Body Analysis System (Model: BC 418, Tanita Corporation, Tokyo, Japan). The following formula was used to calculate BMI: weight $(\mathrm{kg}) /$ height $\left(\mathrm{m}^{2}\right)$. 
Inclusion criteria were lateral elbow pain provocation with at least one of these tests; resisted wrist extension or passive stretch of wrist extensors in the dominant hand. Exclusion criteria were having these symptoms in the nondominant hand, and for more than 12 weeks, having been given physical therapy or corticosteroid injections during that period, having cervical spondylitis, diabetes mellitus, neuropathy, arthritis in the upper extremities, pregnancy, and allergic reactions to $\mathrm{KT}$.

The patients were randomly grouped in two as "inhibitory KT" (IKT) and "sham KT" (SKT). Both groups were given conventional therapy (cold pack and transcutaneous electrical nerve stimulation (TENS) for 15 sessions (3 weeks and 5 days a week). Both groups received KT application every other day by IKT and SKT protocols. Pre-treatment and post-treatment pain, quick disability of the arm, shoulder, and hand questionnaire (Quick DASH) HGS and VRT-ART measurements were performed and recorded.

\section{Treatment Protocol}

Cold pack (placed within a moist towel for 15 minutes around the elbow joint) and TENS (an asymmetrical biphasic waveform and burst modulation, with a current width of 10-60 mm and pulse frequency of 60-120 Hz) were applied with Compex Theta MI Pro to the elbows of the patients for 20 minutes five days a week and a total of 3 weeks. ${ }^{16}$

\section{KT Application}

KT was applied on the skin above the wrist extensor muscles of the symptomatic forearm by a certified physiotherapist by following the directions of Kase et al. ${ }^{17}$ In IKT condition, KT was applied from the direction of insertion (radial styloid process) to origin (lateral epicondyle) with $125 \%$ of its original length, providing muscle inhibition effects. ${ }^{17}$ While holding the wrist in a neutral position, the elbow was slightly flexed to apply KT. In the SKT condition, KT was applied from the direction of origin to insertion, without additional tension on the tape.

\section{Pain Analysis}

A visual analog scale (VAS) was used to evaluate pain in the affected elbow. On a $10-\mathrm{cm}$ ruler, the right and left ends of which showed $0=$ no pain and $10=$ unbearable pain, respectively, the patients were asked to mark the level of their pain and the distance they marked was measured from the ruler's left end. ${ }^{18}$. The patients were asked to evaluate their pain severities at rest (VAS-R), with movements (VAS-M), and at night (VAS-N) separately.

\section{Quick DASH}

The patient's disability level resulting from the upper extremity was evaluated with the DASH scale. In the test which is conducted to evaluate function in the upper extremity with 11 different questions, each activity is graded from 'good' to 'bad' between $1=$ no difficulty and 5=not being able to do at all. ${ }^{19}$

\section{HGS Measurement}

HGS was measured with a Jamar hand dynamometer (Lafayette Instrument Company, USA), which is considered as the gold standard due to its high validity and reliability in many studies and which is advised by the American Society of Hand Therapists. ${ }^{20}$ The measurement was made in the sitting position, the standard position recommended by ASHT, with the shoulder in adduction and neutral rotation, the elbow at $90^{\circ}$ flexion, the forearm in midrotation, and the wrist in the neutral position. ${ }^{21}$ The average of three measurements was recorded in kilograms $(\mathrm{kg})$. To prevent muscle fatigue effects, measurements were performed between 10:00 a.m. and 2:00 p.m. on the affected hand. Before each measurement, an interval of one-minute was given.

\section{RT Measurements}

Hubbard Scientific Reaction Timer (Model: 6027, USA) was used for the VRT and ART measurements of the subjects. Two different warnings can be given with a reaction timer device as a visual (light) and auditory (sound). An environment with no noise and with sufficient light was preferred to make RT measurements between 09:30 and 11:00 a.m. RT measurement results were recorded on information forms prepared for each subject. The participants were asked to put their affected hands on the table placed in front of them. On this table, there was a reaction 
timer that was $10 \mathrm{~cm}$ away from the button. The participants were instructed to press this button in the shortest time possible when a sound or light stimulus was given with the command "ready". Measurement papers prepared beforehand were used to record the results. Each participant made 10 trials for sound and light stimuli, the first five of which were practice trials. The last five trials were accepted as RT. ${ }^{22,23}$

\section{Statistical Analysis}

Kolmogorov Smirnov test was used to find out whether the data were normally distributed, and it was found that the data were not normally distributed. Age, height, weight, BMI, and pre-test, and post-test VAS, VRT, ART, HGS, and DASH scores of the patients who participated in the study were compared with the Mann-Whitney U test. Wilcoxon test was applied to the data to compare pre-treatment and post-treatment VAS-R, VAS-M, VAS-N, VRT, ART, HGS, and DASH scores of the patients in IKT and SKT groups. Median and minimum (min) and maximum (max) values were used to show the data which were not normally distributed. $\mathrm{p}<0.05$ was considered as statistically significant. IBM SPSS Statistics 22.0 for Windows program was used for statistical analysis.

\section{RESULTS}

Median (min-max) values of age, height, weight, and BMI variables of the patients in the study and Mann-Whitney $U$ analysis results are shown in Table 1. According to analysis results, the variables of age, height, weight, and BMI were not found to be statistically significantly different between IKT and SKT groups. (p values are 0.86, 0.277, 0.986 and 0.147 , respectively) (Table 1 ).

Table 1: Median (min-max) values of age, height, weight and BMI and Mann Whitney U analysis results.

\begin{tabular}{|c|c|c|c|c|}
\hline Group & $\begin{array}{c}\text { Age } \\
\text { (years) }\end{array}$ & $\begin{array}{l}\text { Weight } \\
(\mathrm{kg})\end{array}$ & Height $(\mathrm{cm})$ & $\mathrm{BMI}(\mathrm{kg} / \mathrm{m} 2)$ \\
\hline IKT & $\begin{array}{c}48 \\
(28-67)\end{array}$ & $\begin{array}{c}70 \\
(55-102)\end{array}$ & $\begin{array}{c}165 \\
(155-189)\end{array}$ & $\begin{array}{c}25.7 \\
(20.2-32.9)\end{array}$ \\
\hline SKT & $\begin{array}{c}51 \\
(24-65)\end{array}$ & $\begin{array}{c}74 \\
(52-100)\end{array}$ & $\begin{array}{c}165 \\
(150-180)\end{array}$ & $\begin{array}{c}26.8 \\
(17.5-40)\end{array}$ \\
\hline $\mathrm{P}$ value & .860 & .277 & .986 & .147 \\
\hline
\end{tabular}

Table 2 includes the median (min-max) values of pre-treatment and post-treatment VAS-R, VAS-M, and VAS-N scores of the patients in the study and Mann-Whitney U analysis results. According to analysis results, there was a statistically significant difference between IKT and SKT groups in post-treatment VAS-M $(\mathrm{p}=0.00)$ and VAS-N $(\mathrm{p}=0.01)$ scores. Table 2 shows that VAS-M and VAS-N were decreased.

Table 2. Median (min-max) values of pre-treatment and posttreatment VAS-R, VAS-M, and VAS-N scores of the groups and Mann Whitney $\mathrm{U}$ analysis results.

\begin{tabular}{ccccccc}
\hline \multirow{3}{*}{ Group } & \multicolumn{3}{c}{ Pre-treatment } & \multicolumn{3}{c}{ Post-treatment } \\
\hline & VAS-R & VAS-M & VAS-N & VAS-R & VAS-M & VAS-N \\
& & & & & & \\
IKT & 5 & 7 & 9 & 3 & 4 & 4 \\
& $(0-10)$ & $(2-10)$ & $(0-10)$ & $(0-10)$ & $(0-9)$ & $(0-9)$ \\
& & & & & & \\
SKT & 5 & 7 & 6 & 4 & 5 & 5 \\
& $(2-10)$ & $(3-10)$ & $(1-10)$ & $(1-7)$ & $(3-9)$ & $(1-9)$ \\
p & & & & & & \\
value & .224 & .758 & .411 & .165 & .000 & .001 \\
\hline
\end{tabular}

(IKT: Inhibitory kinesio taping, SKT: Sham kinesio taping, VAS-R: Visual analog scale- Rest, VAS-M: Visual analog scale- Motion, VAS-N: Visual analog scale- Night)

Table 3 shows median (min-max) values of pre-treatment and post-treatment VRT, ART, HGS, and DASH scores of the patients in the study and Mann-Whitney U analysis results. According to analysis results, there were no statistically significant differences between IKT and SKT groups in pre-treatment VRT $(\mathrm{p}=0.25)$, ART $(\mathrm{p}=0.69)$, HGS $(\mathrm{p}=0.431)$, and DASH $(\mathrm{p}=0.72)$ scores. There was a statistically significant difference between IKT and SKT groups in post-treatment VRT $(\mathrm{p}=0.00), \operatorname{ART}(\mathrm{p}=0.00)$, and HGS $(\mathrm{p}=0.28)$ scores. Table 3 shows that VRT and ART decreased while HGS increased.

Table 3. Median (min-max) values of pre-treatment and posttreatment VRT, ART, HGS, and DASH scores and Mann Whitney $\mathrm{U}$ analysis results.

\begin{tabular}{llcclc}
\hline $\begin{array}{c}\text { Treat- } \\
\text { ment }\end{array}$ & Group & VRT & ART & HGS & DASH \\
\hline & & 35.8 & 32.2 & 25 & 67 \\
$\begin{array}{c}\text { Pre- } \\
\text { treat- }\end{array}$ & IKT & $(24.9-55.8)$ & $(25.8-51.9)$ & $(10-55)$ & $(35-100)$ \\
ment & SKT & $(24.8-88)$ & $(21.6-99.6)$ & $(5-60)$ & $(25-100)$ \\
& p value & .250 & .069 & .431 & .072 \\
& & 30.4 & 28.2 & 25 & 41 \\
Post- & IKT & $(14.4-62.4)$ & $(11.2-37.2)$ & $(14-60)$ & $(20-62)$ \\
treat- & & 33.6 & 32.8 & 21 & 45 \\
ment & SKT & $(18.8-81.8)$ & $(20.2-80.2)$ & $(10-60)$ & $(20-90)$ \\
& p value & .000 & .000 & .028 & .067 \\
\hline
\end{tabular}

(IKT: Inhibitory kinesio taping, SKT: Sham kinesio taping, VRT: Visual reaction time, ART: Auditory reaction time, HGS: Handgrip strength, DASH: Quick disability of the arm, shoulder, and hand questionnaire)

Wilcoxon test was applied to the data to compare the pretreatment and post-treatment intragroup VAS-R VAS-M, 
VAS-N, VRT, ART, HGS, and DASH scores of IKT and SKT groups. According to analysis results, there was a statistically significant difference between VAS-R VAS-M, VAS-N, VRT, ART, HGS, and DASH scores of both groups $(\mathrm{p}<0.05)$. Table 4 shows that VAS scores, VRT, ART and DASH scores decreased while HGS increased.

Table 4: Analysis results of pre-treatment and post-treatment VAS-R VAS-M, VAS-N, VRT, ART, HGS, and DASH scores.

\begin{tabular}{lllllllll}
\hline \multirow{2}{*}{ Group } & \multicolumn{9}{c}{ VAS } & \multicolumn{9}{c}{ RT } & HGS & DASH \\
& $\begin{array}{l}\text { VAS- } \\
\text { R }\end{array}$ & $\begin{array}{l}\text { VAS- } \\
\text { M }\end{array}$ & VAS- & N & VRT & ART & & \\
\hline IKT & .000 & .000 & .000 & .000 & .000 & .000 & .000 & .000 \\
SKT & .000 & .000 & .000 & .000 & .000 & .014 & .003 & .000 \\
\hline
\end{tabular}

(IKT: Inhibitory kinesio taping, SKT: Sham kinesio taping, VAS-R: Visual analog scale- Rest, VAS-M: Visual analog scale- Motion, VAS-N: Visual analog scale- Night, RT: Reaction time VRT: Visual reaction time, ART: Auditory reaction time, HGS: Handgrip strength, DASH: Quick disability of the arm, shoulder, and hand questionnaire)

\section{DISCUSSION}

This study aimed to evaluate the IKT and SKT applied in addition to conventional physiotherapy methods on VAS, VRT, ART, HGS, and DASH scores. In the intragroup comparisons of pre-treatment and post-treatment effects, a statistically significant decrease was found in all parameters of VAS, VRT, and ART scores, and a statistically significant increase in HGS and DASH parameters. In the post-treatment comparisons of both groups, it was concluded that VAS-M, VAS-N, VRT, and ART results differed statistically significantly in favor of the IKT group.

It is reported in the literature that criteria such as a decrease in pain, degeneration control, increase in functionality, recovery in motor strength should be completed to be able to say that conservative treatment is successful in LE. ${ }^{24}$ It is known that a large number of methods are used in the conservative treatment of LE to provide these clinical gains and it is noteworthy that one of the frequently used methods is KT. ${ }^{12,14,25}$ The use of KT in the clinic has increased with the evidence that it provides a reduction in pain by resting the excessively activated muscles in tendinopathies, reducing the excessive stress on the tendon and joints, regulation of joint biomechanics, and mechanoreceptor activation. ${ }^{14}$ Nevertheless, research on KT is very limited. It can be seen that the source of literature on KT application is based on the manufacturer. ${ }^{8,26}$ For this reason, literature evidence about KT gains importance. In ad- dition to studies reporting that KT is effective in pain regulation in musculoskeletal system diseases, there are also studies that report that there is no change in pain. ${ }^{12,25}$ Since pain is the main complaint of LE patients, it is the most frequently used parameter in evaluation and outcome measurements. In the present study, progress was found in post-treatment values in all forms of pain when compared with pre-treatment values for both groups. In post-treatment comparisons of both groups, it was concluded that VAS-M, VAS-N results showed a significant decrease in the IKT group.

The increase in HGS as a result of conservative treatment of LE is also proof of the effectiveness of the treatment. ${ }^{13}$ However, it is seen that the effects of KT application on grip strength are contradictory in the literature. ${ }^{12,24,27,28}$ This may be due to the differences in the methods applied and HGS measurement methods. As a result of this study, no statistically significant differences were found between groups in post-treatment HGS evaluations, and a significant increase was found in both groups in terms of pretreatment-post-treatment intragroup evaluations. The contribution of mechanoreceptors, which are facilitated by the elimination of pain, to increase the activation of motor units may explain the improvement in HGS. ${ }^{29}$

Although it is seen that the effects of KT application on conservative treatment of LE, such as pain, grip strength, and functional life activities, are frequently examined in the accessible literature and, no studies are evaluating its effect on VRT and ART. It has been reported in a study that chronic musculoskeletal pain delays the reaction time. ${ }^{11}$ As a result of this study, a statistically significant decrease was found in the motor component of RT, which is known to be the first response to decreasing pain, visual and auditory stimuli, and VRT and ART scores due to decreasing VAS scores. In intragroup comparisons, there was a statistically significant decrease in VRT, ART scores of both groups; however, when post-treatment scores were compared, the decrease in the IKT group was found to be statistically significant. While it is a limitation for the discussion part that this is the first study in the literature, it is thought that the study will be a basis for new studies in the field. 
The limitation of present study is that it could not reveal the long-term treatment results due to patient incompatibility. The fact that this study is the first study in this field creates a limitation for the discussion section, but it will form the basis for new studies in this area.

As a conclusion, it was found that in the conservative treatment of LE, the use of KT in addition to conventional physiotherapy modalities increased the efficiency of the treatment. It is noteworthy that in addition to VAS, HGS, DASH scores, VRT, and ART scores which were not previously evaluated in this field also shorten RT. It is thought that the evaluation of RT in musculoskeletal system diseases in which the motor component of movement is affected will contribute to the literature.

\section{Conflict of Interests}

The authors declare that there is no conflict of interests.

\section{Author Contribution Rate}

Concept/Design: ŞT, YE. Data Collection and/or Processing: FK, RÇ. Data analysis and interpretation: DŞ. Literature Search: ŞT, FK, DŞ. Drafting manuscript: ŞT, RÇ. Critical revision of manuscript: ŞT, YE. Supervision: YE.

\section{REFERENCES}

1. Gürçay E, Tamkan AU, Karaahmet ÖZ, Tombak Y, Güzel, S, Cakci A. Depression and Somatization in Refractory Lateral Epicondylitis. Arch of Rheum. 2019;34(4):367370.

2. Meyer NJ, Walter F, Haines B, Orton D, Daley RA. Modeled evidence of force reduction at the extensor carpi radialis brevis origin with the forearm support band. J Hand Surg. 2003;28(2):279-287.

3. Kraushaar BS, Nirschl RP. Tendinosis of the elbow (tennis elbow). Clinical features and findings of histological, immunohistochemical, and electron microscopy studies. J Bone Joint Surg Am. 1999;81(2):259-278.

4. Keus SHJ, Smidt N, Assendelft WJJ. Treatment of lateral epicondylitis in general practice: result of a survey. Eur Gen Pract. 2002;8(2):71-72.

5. Chard MD, Hazleman BL. Tennis elbow-a reappraisal. $\mathrm{Br}$ J Rheumatol. 1989;28(3):186-190.

6. Waseem M, Nuhmani S, Ram CS, Sachin Y. Lateral epicondylitis: a review of the literature. J Back Musculoskelet Rehabil. 2012;25(2):131-142.

7. Kase K, Wallis J, Kase T. Clinical therapeutic applications of the kinesio taping method (2nd edition). Tokyo, Japan: Ken Ikai Co. Ltd.; 2003

8. Kaya E, Zinnuroglu M, Tugcu I. Kinesio taping compared to physical therapy modalities for the treatment of shoulder impingement syndrome. Clin Rheumatol. 2011;30(2):201207.
9. Bunce D, MacDonald SWS, Hultsch DF. Inconsistency in serial choice decision and motor reaction times dissociate in younger and older adults. Brain Cogn. 2004;56(3):320327.

10. Ganong WF. Review of Medical Physiology. San Francisco. McGraw-Hill. 2001;49-51.

11. Cai Y, Leveille SG, Hausdorff JM, et al. Chronic Musculoskeletal Pain and Foot Reaction Time in Older Adults. J Pain. 2021;22(1):76-85.

12. Dilek B, Batmaz I, Sarıyıldız MA, et al. Kinesio taping in patients with lateral epicondylitis. J Back Musculoskelet Rehabil. 2016;29(4):853-858.

13. Korthals-de Bos IB, Smidt N, Van Tulder MW, et al. Cost effectiveness of interventions for lateral epicondylitis: results from a randomised controlled trial in primary care. Pharmacoeconomics. 2004;22(3):185-195.

14. Fu TC, Wong AM, Pei YC, Wu KP, Chou SW, Lin YC. Effect of Kinesio Taping on Muscle Strength in Athletes: A Pilot Study. JSAMS. 2008;11(2):198-201.

15. Oldfield RC. The assessment and analysis of handedness. The Edinburgh inventory. Neuropsychologia. 1971;9(1):97-113.

16. Sayegh ET, Strauch RJ. Does nonsurgical treatment improve longitudinal outcomes of lateral epicondylitis over no treatment? A meta-analysis. Clin Orthop Relat Res. 2015;473(3):1093-1107.

17. Kase K, Wallis J, Kase T. Clinical therapeutic applications of the kinesio taping method ( $2^{\text {nd }}$ edition). Tokyo, Japan: Ken Ikai Co. Ltd.;2003.

18. Hawker GA, Mian S, Kendzerska T, French M. Measures of adult pain: Visual analog scale for pain (vas pain), numeric rating scale for pain (nrs pain), McGill pain questionnaire (mpq), short-form McGill pain questionnaire (sf$\mathrm{mpq}$ ), chronic pain grade scale (cpgs), short form-36 bodily pain scale (sf-36 bps), and measure of intermittent and constant osteoarthritis pain (icoap). Arthritis Care Res. 2011;63(11):240-252.

19. Dogan SK, Ay S, Evcik D, Baser O. Adaptation of Turkish version of the questionnaire Quick Disability of the Arm, Shoulder, and Hand (Quick DASH) in patients with carpal tunnel syndrome. Clin Rheumatol. 2011;30(2):185-191.

20. Bohannon RW, Schaubert KL. Test-retest reliability of grip-strength measures obtained over a 12-week interval from community-dwelling elders. $J$ Hand Ther. 2005;18(4):426-427

21. Fess EE. Grip Strength, 2nd edition. Chicago: American Society of Hand Therapists; 1992.

22. Gavkare AM, Nanaware NL, Surdi AD. Auditory reaction time, visual reaction time and whole body reaction time in athletes. Ind Med Gaz. 2013;6:214-219.

23. Senol D, Kisaoglu A, Canbolat M, et al. Are visual and auditory reaction times influenced by Ramadan fasting? Neuro performance study on healthy individuals. Ann Med Res. 2019;26(9):1751-1754

24. Waseem M, Nuhmani S, Ram CS, Sachin Y. Lateral epicondylitis: A review of the literature. J Back Musculoskelet Rehabil. 2012;25(2):131-142.

25. Vicenzino B. Lateral epicondylalgia: A musculoskeletal physiotherapy perspective. Man Ther. 2003;8(2):66-79.

26. Kase K, Wallis J. The latest Kinesio taping method Tokyo. Ski J. 2002;35-40.

27. Thelen MD, Dauber JA, Stoneman PD. The clinical efficacy of kinesio tape for shoulder pain: a randomized, double-blinded, clinical trial. J Orthop Sports Phys Ther. 2008;38(7):389-395

28. Liu YH, Chen SM, Lin CY, Huang CI, Sun YN. Motion tracking on elbow tissue from ultrasonic image sequence for patients with lateral epicondylitis. 2007 Annu Int Conf IEEE Eng Med Biol Soc, Lyon, France, 2007;95-98.

29. Słupik A, Dwornik M, Białoszewski D, Zych E. Effect of Kinesio Taping on bioelectrical activity of vastus medialis muscle. Preliminary report. Ortop Traumatol Rehabil. 2007;9(6):644-651. 